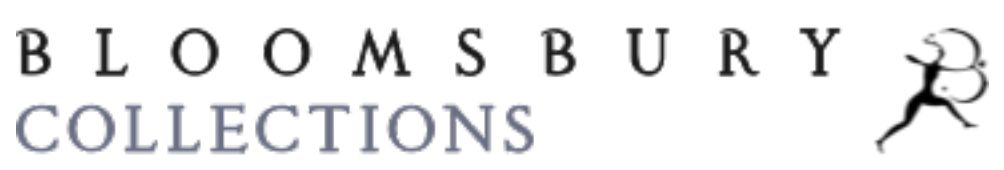

Balnaves, Mark, and Gary Madden. "Social games and game-based revenue models." Social, Casual and Mobile Games: The changing gaming landscape. Ed. Tama Leaver and Michele Willson. New York: Bloomsbury Academic, 2015. 195-212. Bloomsbury Collections. Web. 26 Apr. 2023. <http://dx.doi.org/10.5040/9781501310591.ch-014>.

Downloaded from Bloomsbury Collections, www.bloomsburycollections.com, 26 April 2023, 12:20 UTC.

Copyright (C) Tama Leaver, Michele Willson and Contributors 2016. You may share this work for non-commercial purposes only, provided you give attribution to the copyright holder and the publisher, and provide a link to the Creative Commons licence. 


\title{
14
}

\section{Social games and game-based revenue models}

\author{
Mark Balnaves and Gary Madden
}

\begin{abstract}
asual, social games are estimated to engage more than 200 million worldwide with revenues of US\$6 billion on mobile, iPhone, social networks, PC, Mac, Xbox LIVE Arcade platforms (CGA 2013). The name of the game is freemium for this economy. Freemium provides players with free access to games. Those players who want to upgrade the look and feel of the game or other additional amenities pay for it. Tetris, created in a Soviet lab, was arguably the first casual game, tied to the Japanese Game Boy in its creation. Tetris was also the first casual game to show the possibilities of monetization of this phenomenon. In this chapter the authors look at the games-based revenue models and how they are evolving, providing a background to the development of the industry itself.
\end{abstract}

\section{Consoles and platforms}

The monetization of games has emerged because of a complex interaction between the technologies of gaming, the technologies of cooperation - the capacity to interact with other players - and games design itself (Juul 2012). Table 14.1 demonstrates this trajectory in the different generations of game 
Table 14.1 Console generations

\begin{tabular}{|c|c|c|}
\hline Generations & Period & Distinctive features \\
\hline First & $1972-6$ & $\begin{array}{l}\text { Logic circuits/ but no-microprocessor } \\
\text { (e.g. Magnavox Odyssey, Pong) }\end{array}$ \\
\hline Second & 1977-84 & $\begin{array}{l}\text { 8-bit machine / Replaceable ROM } \\
\text { cartridge flexibility } \\
\text { (Atari 2600, Intellivision) }\end{array}$ \\
\hline Third & $1985-9$ & $\begin{array}{l}\text { 8-bit / Mega drive } \\
\text { (e.g. Nintendo Entertainment System or } \\
\text { NES in the US market, and Sega Master } \\
\text { System in Europe, Atari 7800) }\end{array}$ \\
\hline Fourth & $1990-5$ & $\begin{array}{l}\text { 16-bit / Nintendo, Sega, handheld } \\
\text { (Super NES, Game Boy System, PC-Engine) }\end{array}$ \\
\hline Fifth & $1996-2000$ & $\begin{array}{l}\text { 32-bit and then by 64-bit / Rise of 3D games } \\
\text { (e.g. Sony PlayStations, Nintendo 64) }\end{array}$ \\
\hline Sixth & 2001-05 & $\begin{array}{l}\text { 128-bit / Built-in modem for Internet } \\
\text { support and online play (Sony } \\
\text { PlayStation 2, Nintendo Game Cube, } \\
\text { Microsoft Xbox) }\end{array}$ \\
\hline Seventh & 2006-10 & $\begin{array}{l}\text { High definition (HD) graphics / Wi-Fi } \\
\text { connectivity (e.g. Sony PlayStation 3, } \\
\text { Nintendo Wii, Microsoft Xbox360). }\end{array}$ \\
\hline $\begin{array}{l}\text { Eighth } \\
\text { (Current) }\end{array}$ & $\begin{array}{l}2011- \\
\text { present }\end{array}$ & $\begin{array}{l}\text { Platformization, Built-in Touch Screen / } \\
\text { sensor perceived motion control (e.g. } \\
\text { Nintendo 3DS, PlayStation vita, Xbox One) }\end{array}$ \\
\hline
\end{tabular}

platform and technologies. By the eighth generation players can interact with others on consoles and the consoles themselves are now platforms for other services in an online environment.

Before the console generation began, the first commercially launched video game was arcade type. Bushnell and Dabney created coin-operated 'space war' that was subsequently bought by Nutting Associates. They manufactured and released 1,500 pieces of the game in November 1971, though it was a failure because of its steep learning curve. Bushnell and Dabney founded Atari Incorporated in 1972 and released another arcade game, Pong, which was highly successful and sold about 19,000 Pong machines that year. 
The first-generation consoles were based on dedicated logic circuits without any microprocessor. Once a game was created, it was not possible to add new features or change it. Magnavox first released Odysseys through the home console in 1972 for the US market and succeeded in selling 100,000 Odysseys that year. The second-generation consoles appeared in 1977 with a replaceable cartridge feature. The flexibility of changing cartridge made it possible for players to build their own libraries of game collections. The arcade game and console market went hand in hand. The game market, however, crashed in 1977 when old Pong machines and other clones were re-sold at a very low stock-clearing price. Fairchild and RCA left the home console market while Atari and Magnavox operated with losses. The game market returned with the release of 'space invader' in 1978. This application enabled Atari to quadruple sales and recover from earlier losses (see also Castronova 2006).

The game industry faced another crash in 1983, but not before the arcade and console market had gained combined revenue of US\$11.8 billion in 1982 . For the first time the game market surpassed the combined revenue of popular music (US\$4 billion) and Hollywood films (US\$3 billion) (Castronova 2006). A mid-1980s crash was marked by the demise of the second generation and subsequent rise of the third-generation consoles. Nintendo Entertainment System (NES) and Sega Master System (SMS) dominated respectively the North American and the European market with their 8-bit machines in this period. Cartridges were losing popularity to CDs because of the lower cost and reliability of CDs.

The fourth-generation console came up with a CD feature in 16-bit machines. PC-Engine released in this period by NEC faced severe competition from rival products such as Sega Mega Drive, CDi and Atari Jaguar. Game Boy - a handheld battery-powered plastic device - released players from arcade rooms. It was bundled with a single cartridge Tetris. Tetris is a simple puzzle game with the sole goal of rotating falling blocks in order to build the most efficient walls. Tetris's graphics were worked well on the Game Boy's small grey-scale screen with no blur in the motion. The pairing of Game Boy and Tetris sold more than 70 million copies. Tetris is the forerunner of Angry Birds, Bejeweled, Fruit Ninja and key casual games (Heeks 2010a/b).

Video consoles entered the fifth generation with 3D games. Nintendo 64 and Sony PlayStation were two popular products of this era. In the sixth generation Microsoft Corporation entered the console market with Xbox, while Sega left the hardware market. Although others had already adopted CD drives for their games, Nintendo for the first time introduced its game cube consoles. Increasingly complex, sophisticated and adult content were being introduced in the console-based games. Easy access to Internet services with faster connectivity took the gaming world online into the seventh generation. 
EverQuest, World of Warcraft and Ultima Online became highly successful massively multiplayer online role-playing games (MMORPGs). As memory and processing power of mobile phones increased, mobile phones also became a popular platform for playing games. Revenue from mobile gaming market surpassed US $\$ 5$ billion in 2007 accounting for one-fourth of all game software revenue (Woodcock 2008). Nokia's N-series and Apple's iPhone were active in this market. Motion control systems started to constantly revolutionize the interaction methods in gameplay. Sony released PlayStation Move in 2010 that tracks player movements with an eye camera. MMORPGs also dovetailed with the growth of virtual currency platforms. Virtual currency in these contexts often had unexpected effects:

Massively multiplayer online role-playing games (MMORPGs) - such as World of Warcraft and EverQuest /I - attract an estimated 50 million players worldwide. To excel at these games and move to higher levels, gamers need to accrue a certain amount of wealth, which can be very time consuming. Filling this niche, an estimated 100,000 to one million gold farmers, mostly concentrated in China, spend their days in gaming factories amassing virtual gold in various MMORPGS which they then sell to other players. This is a sizable industry, which may bring in as much as $\$ 1$ billion in annual trade. But ... this is a controversial practice, and though it helps thousands of gold farmers earn wages equal to those of factory workers, it goes against the rules of the games. In fact, companies that market online games are retaliating by either banning players who they believe are gold farmers or by taking legal action against them. (Seto 2009; Yoon 2009; Heeks 2010b; see also Paying for Pixels 2011; Dibbell 2012)

In the eighth generation, platformization, cross-platform game market there is now high-speed Internet in industrialized countries, established payment systems built into games and mobility. There is also a decline in the value of console hardware and increasing value in software. The mobile side of the games economy platforms has also emerged as key for the future.

Thus, a new approach emerged from 2008 . . . It consists of a 'platformisation' of the mobile ecosystem in which main players group together - in a loosely or tight cooperative scheme - all the required roles for the provision of the mobile offering on a common set of hardware, software and techno-economic specifications. The resulting scheme reduces transaction costs (agreements are typically pre-defined) and also development costs as far as the resulting platform is massively adopted by final users. Each platform includes a number of 'gatekeeper' roles as a 
way to control the evolution of the platform and to secure the revenues. In the case of mobile games the crucial roles would be: (i) the development environment, i.e., a set of development and hosting tools for third-party service developers such as game studios and publishers; (ii) the profile/ identity/context management: a component that manages user data and user preferences for different situations; (iii) the provisioning/brokerage: it represents the reference point for end-users to retrieve, subscribe and use games (ownership of an application store as a main example); and (iv) charging and/or billing of mobile games. Control over one or a combination of these four roles can lead to platform dominance within the ecosystem. Therefore, new platforms are emerging trying to include as many of these roles as possible in a new type of competition. (Feijoo 2012, 81)

Apple's App Store now accounts for 65 per cent of total mobile revenues globally, with Google Play in the background. Much of Apple's success is due to the success of games monetization across all countries, accounting for 71 per cent of total revenues (Distimo, October 2013). In the overall games market it is the multi-screen use, the time spend that is seen as a key to future revenue generation (Lehdonvirta 2009; Lescop and Lescop 2014; Rayna and Striukova 2014).

The authors argue that it is not possible to separate the rise of social, casual games from the rise of the game industry as a whole and its technologies. The dominance of the console market is being challenged by the emergence of new players and new platforms. By the time that Facebook trialled its first games Barn Buddy and Happy Farm in 2009, the technologies already enabled sophisticated social interaction. Facebook management already had access to data on the success of earlier casual games in the console markets, for example Tetris. What was new in Facebook as a technology of cooperation was in the virtual currencies that went with the games and the provision of high-quality graphics with the simple casual games such as Farmville. Facebook, in effect, became a platform for casual games development, as the list of top content providers to Facebook in 2011 demonstrates.

Facebook's experience demonstrated to the games business that while only 1-5 per cent of a social game's audience purchase virtual items, the big spenders were key to success. The big spender spends more than US $\$ 25$ per month, on average. Big spenders represent only 15 per cent of a game's paying users, but account more than 50 per cent of revenue. Most payers spend only US $\$ 1-5$ a month and generate less than 15 per cent of a game's revenue, in aggregate. The social games revenue stream is 20 per cent from advertising, 20 per cent from offers and 60 per cent from virtual goods (De Prato et al. 2010; CGA 2013). 
Table 14.2 Top content providers to Facebook 2011 against daily active users (DAU)

\begin{tabular}{|c|c|c|}
\hline & & DAU \\
\hline 1 & Zynga & $46,040,192$ \\
\hline 2 & Electronic Arts & $12,367,782$ \\
\hline 3 & Wooga & $7,518,000$ \\
\hline 4 & 6waves Lolapps & $5,306,300$ \\
\hline 5 & King.com & $5,270,000$ \\
\hline 6 & PeakGames & $4,580,400$ \\
\hline 7 & Playdom & $3,890,330$ \\
\hline 8 & Tetris Online & $2,100,120$ \\
\hline 9 & GSN & $1,852,292$ \\
\hline 10 & Happy Elements & $1,866,700$ \\
\hline 11 & Playtika & $1,680,000$ \\
\hline 12 & MindJolt & $1,511,252$ \\
\hline 13 & Digital Chocolate & $1,306,202$ \\
\hline 14 & $\begin{array}{l}\text { DoubleDown } \\
\text { Interactive }\end{array}$ & $1,300,000$ \\
\hline 15 & KIXEYE & $1,079,000$ \\
\hline
\end{tabular}

Source: Casual Games Association 2013.

\section{The value chain and revenue models}

Facebook and Apple have provided platforms where developers can trial games. A number of actors take risks in the production of casual games. From the production of the game to the final consumers the different actors split their share in the total revenue pie according to their cost-sharing, risk-taking and bargaining power. As games enter new generations, various actors reposition themselves on the value chain and revenue models are shaped accordingly. 
Developer: The artistic content of a game and all the technical activities required (e.g. the game engine) are handled by developers. They can act on their own as a small studio selling their products independently to the publishers or through distributors to consumers and assume all the risk involved in monetizing the game. In the case of many casual games the developers have to finance their own activity from their own savings or from venture capital. Alternatively, they can work for publishers and receive an agreed-upon contractual payment stream. Console manufacturers can often have their own in-house developers working for them.

Publishers: Publishers are responsible for bringing the game to the market. Most of the games are funded by publishers during the development phase. As a result, publishers are in effect in control the type of game that appears in the market. Publishers manufacture the game and take its marketing responsibilities. Some well-known publishers in the game industry are Electronic Arts, Sony, Activision Blizzard and Code Masters.

Distributors: Once products are ready for final use, the distributor's role is to make the products available to the consumers from the retail outlets. Introduction of digital distribution has substantially changed the market structure. Digital distribution allows game sellers to cut cost on physical logistics. Developers and publishers can now bypass distributors and retailers to directly deliver the product to the consumers. Retailing jobs are now taken over by portals in the digital age. Yahoo! Games and Orange are two such portals for distributing online casual games. The idea of digital distribution has created a new genre of revenue models based on selling virtual goods online. Almost all current generation consoles (Sony PSN, Microsoft XBLA and Nintendo Wii ware) support online buying of games from digital distribution channels.

Retailers: Consumers have direct contact with retailers who allocate their shelf space for the product and provide customer care and aftersales service to the ultimate buyers. Retailing decisions depend to a large extent on factors such as opportunities for market growth, margins obtained and cost of serving the customers. Although there are no outlets under brand names, some big retailers such as Wal-Mart and FNAC have major shares in the retail sell. Game distribution through retailers has the advantage that the products displayed on shelves acts as advertisements to the general shopper. Buyers who do not have access to online payment systems can still buy the game from retailers. It should be noted that roles played by various actors in the revenue chain are not mutually exclusive. The role played by one party can be taken over by another. Developers, for example, can publish and distribute their own games. In case of online games some new actors can invade the revenue chain. Service providers such as web portal hosting services, credit card companies and network carriers take a big slice of revenue from the distribution channel. 


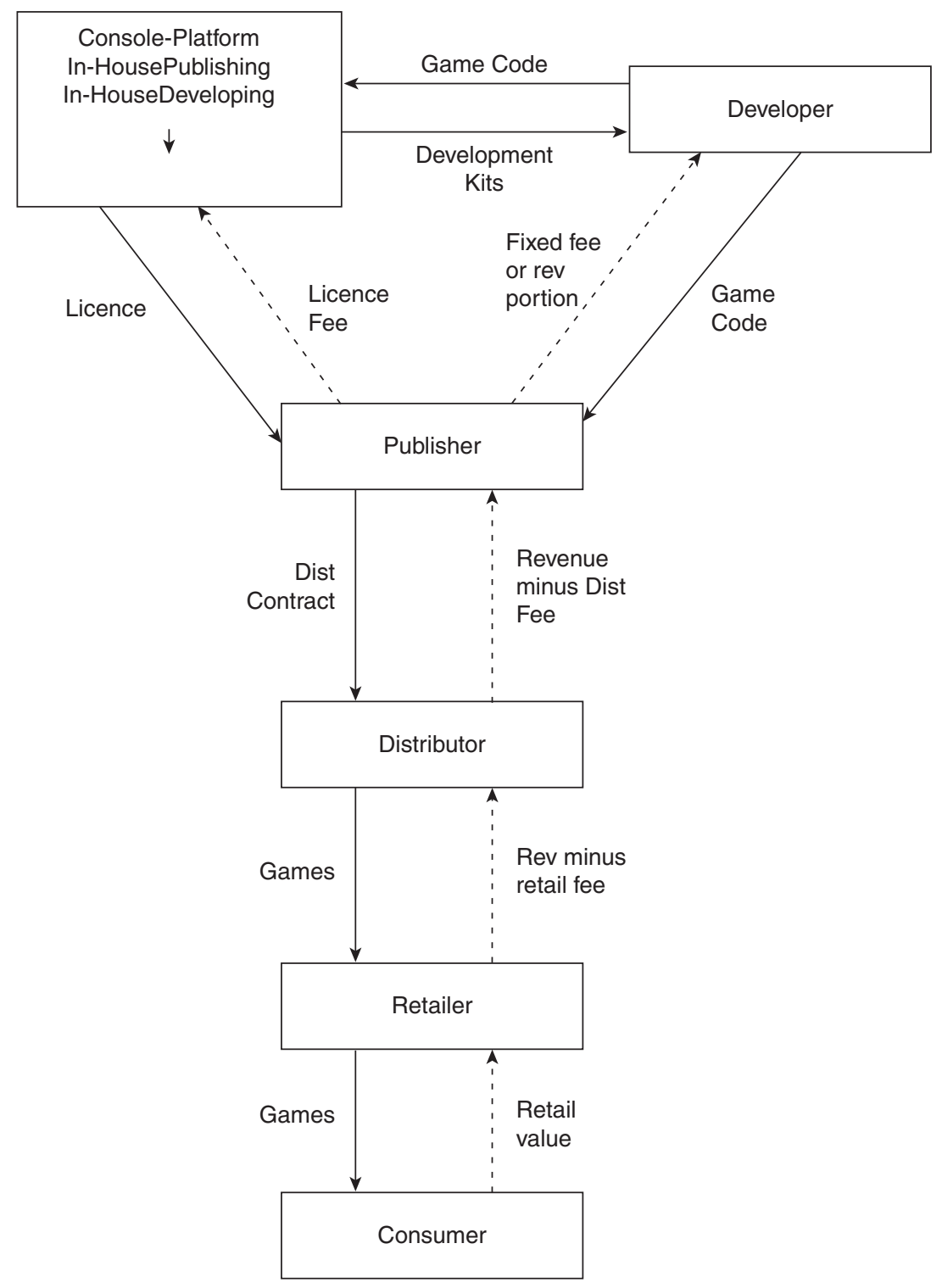

FIGURE 14.1 The traditional games revenue value chain.

Source: Adapted from Phillips et al. 2009.

Figure 14.1 provides an overview of the traditional revenue chain ecosystem for the games economy. Just as there are different roles in the value chain for the games business, there are different revenue models that are possible in the online and offline games markets. 


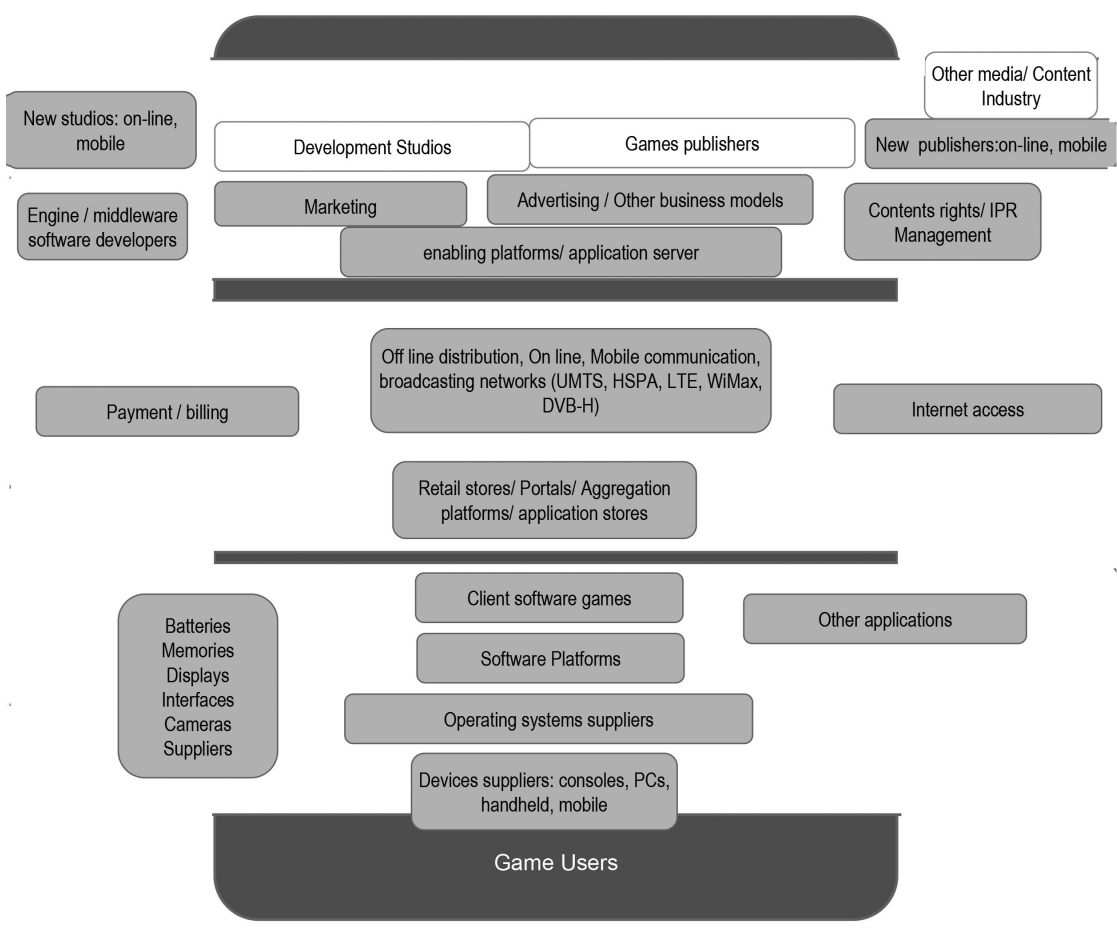

FIGURE 14.2 The new games revenue ecosystem.

Source: Adapted from Simon 2011.

However, in the new games ecosystem and platformization there is now room for new entrants in different segments of the value chain, competing with the traditional market-dominant players. 'Some segments are declining (consoles and PCs), while others are growing fast (online and mobile games). Regions display specificities with the respective share of each platform.' Figure 14.2 shows the new ecosystem showing the dynamism of the modern segments.

\section{Revenue models}

The online and offline games market can be described as a differentiated oligopoly market where a limited number of game producers create their own bundle of multiattribute products for players. Since price competition is intense for homogenous products in the oligopoly market game producers compete in other dimensions. Varieties are introduced in games by segmenting them into action, social interactive or historical legendary types. However, as the gaming population is very large, the market structure supports multiple agents producing similar games. 
There is no single business model that can be applied to all types of games. From the first Pong machine to the latest online casual games, various types of innovative models have been applied to monetize games. Traditional offline games usually apply 'pay - play - stay' strategy while 'play - stay - play' fits well with online games. By 1980s the arcade video game industry had an income of between US\$5-7 billion with 24,000 full arcades, 400,000 street locations deploying 1.5 million arcade video games (Wolf 2008, 4). By 2011 the arcade market had dropped back to US\$1 billion (see also Kocurek 2012). Online games differ in several ways from the offline games. Offline games earn revenue by selling the game once and for all, but the same online game can be sold repeatedly to the same or new customers. Keeping customers interested in the game is important for sustained revenue generation for online games. Wi (2009) defines offline games as retail industry and online games as a service industry. Various types of revenue models can be broadly categorized under offline and online games.

In fact all games producers offer various types of packages to attract a larger customer base. Game-based revenue can also accrue to parties not involved in the revenue chain. Player-to-player trading of virtual goods falls under this type of revenue generation. Skilled players can be employed by a novice to earn in-game item, paying the skilled players with real money. Games are sometimes purchased as investment goods that generate future income flow as they are sold to consumers for pay-per-play or pay-per-time.

Before the introduction of online games in the early 1990s, all games were offline. Browser-based online games are usually played with PC keyboards instead of dedicated joysticks that are integral parts of offline game consoles. Offline games are still popular among some segments of the gaming community. Piracy is a major issue for implementing revenue from offline games. To play online games a player needs to access the server maintained by the game developer or the Internet Service Provider (ISP). Online games are more secure from illegal copying because it does not allow for downloads and game contents are periodically modified to keep players interested in the game.

Online game revenue models have been tailored to meet customer requirements so that maximum participation is ensured. Some players prefer to play multiple games during a month while others stay on a single game. Three types of plans are available to accommodate or attract various types of players.

1 Set amount plan: Users pay a monthly fee for unlimited access to a game. Long-term contracts, for example for three months, are usually cheaper than short-term contracts of one month. Players committed to a particular type of game are attracted to this type of plan. 
2 Set volume plan: Users buy the gameplaying time instead of the calendar time. Players can play the game at their convenience. This type of pre-paid plan is convenient for occasional players.

3 Partial pay plan: The basic concept here is that a part of the game is offered free and the rest is charged. The freemium (free + premium) model, fall under this type of plan. The partial pay model was first applied on the social network sites (SNSs). This has been rapidly adopted by other games as well.

An example of price charged according to the first two plans for the case of World of Warcraft is shown in Table 14.4.

The set amount and set volume plans can be sold at wholesale rates to Internet cafés that can retail on-sell these products according to their own plan. Per computer unlimited access for a specified duration is offered under the first-type of wholesale plan and a large bloc of game-time that can be employed simultaneously over up to seventy computers is offered under the second plan. Internet cafés find it profitable to buy popular games under the first plan and less popular games are suitable under the second plan. Some game companies sell virtual or in-game money through Internet cafés and share profits with them. This is known as an items-cash transaction.

\section{Emerging Chinese markets}

For Bourdieu economic capital literally dominates all other forms of capital, even though there is a 'hierarchy of the different species of capital' across different fields (Bourdieu and Wacquant 2005, 98). Casual games represent a whole economy, a whole system of technology, trade, audiences and community. They are not going to disappear overnight and they are only going to grow. The community side to casual games should not be underestimated in any understanding of games as an economy. The 2014 Chinese Lunar New Year festival (31 January to 14 February) created the largest modern migration of humans with over 3.6 billion trips undertaken within China. WeChat, a Chinese micro-messaging application available globally created a feature called Red Bags to accompany the festival period. The Red Bag digitally imitated the Chinese Lunar New Year tradition of 'hong bao' - 红包 - where elders pass money to the young to encourage prosperity and provide good blessings. The red bags themselves imply a range of expectations that do not need to be made explicit. Unlike the tradition of adults giving physical red packets to children or colleagues, or married couples to unmarried people, the WeChat feature 


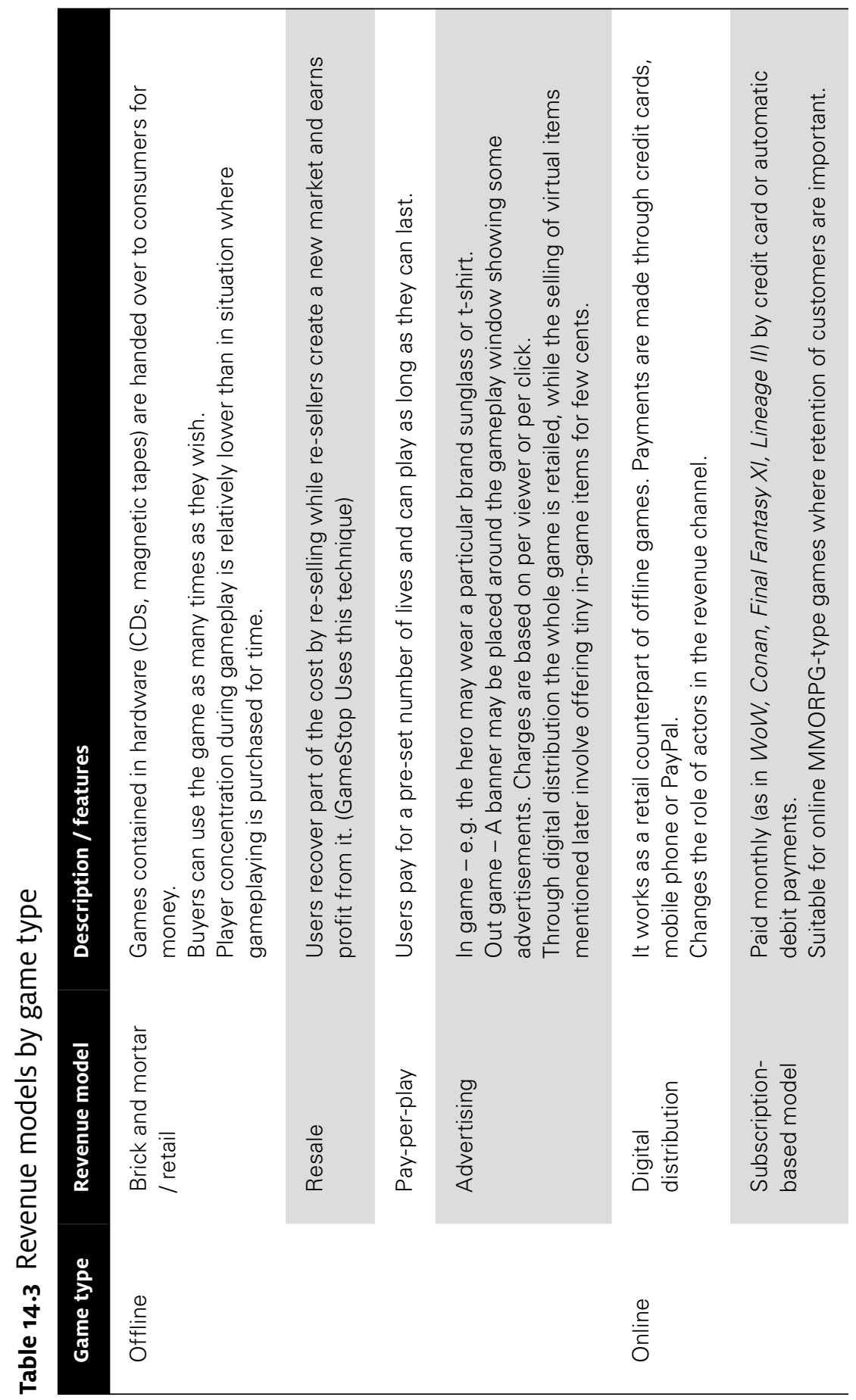




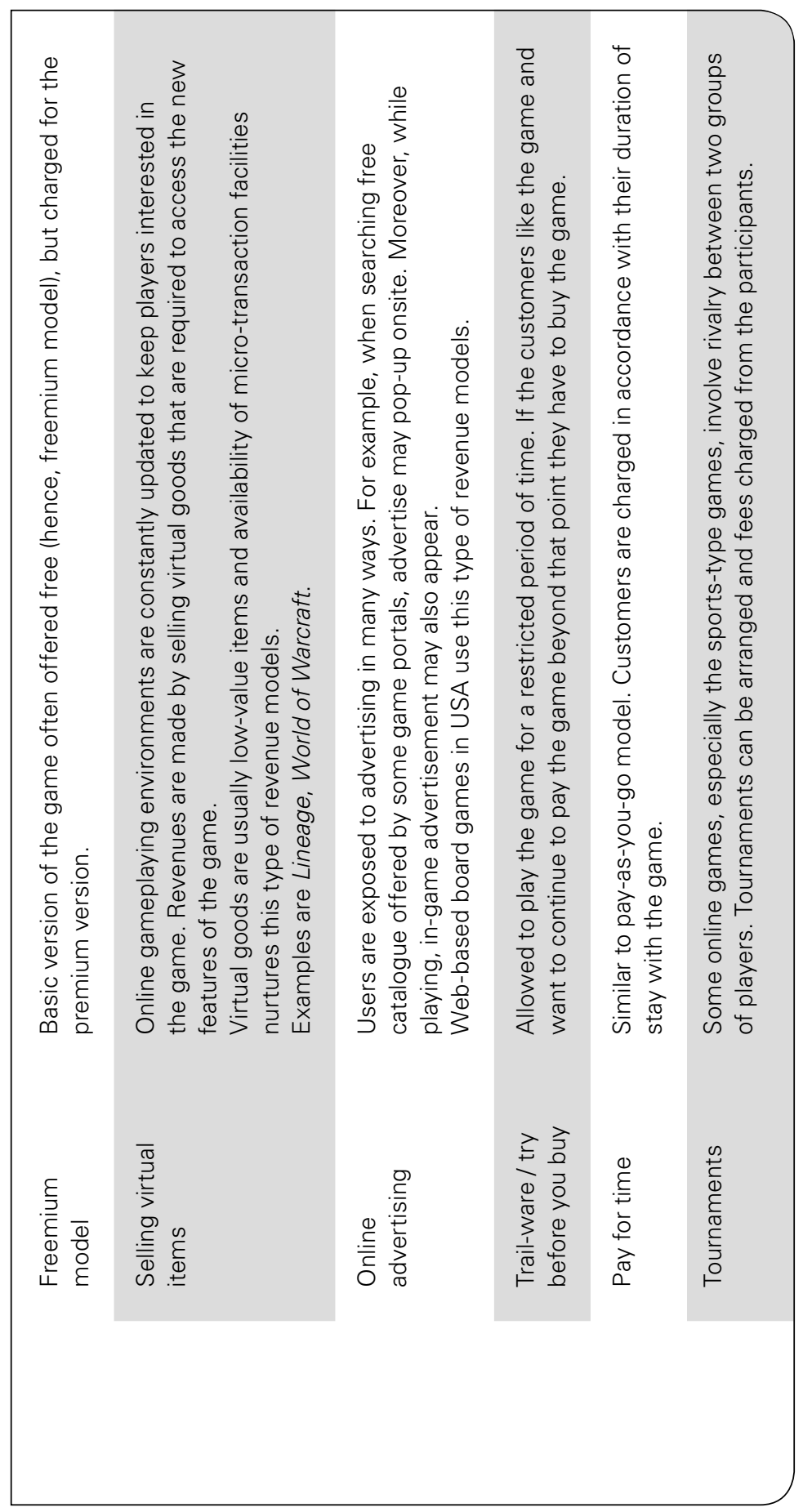


Table 14.4 Product price plan of World of Warcraft (prices in US\$)

\section{Set amount}

7 days (1 week plan) $-\$ 8.80$

30 days (1month plan) $-\$ 25$

90 days (3 months plan) $-\$ 60$
Set volume

5 hours (300 minutes) $-\$ 4$

30 hours $(1,800$ minutes $)-\$ 15$

Source: Wi (2009).

encouraged people to give 'lucky money' to anyone. Red Bags became an instant hit during the Chinese Lunar NewYear festival. Deputy General Manager, Tenpay Group, of WeChat Yi Wu saw in the Red Bags phenomenon the strong tie between casual games and community and the modern economy (Han and Xu 2014). The Red Bags event, at first glance, does not look like a game, but the exchanges and choice of exchanges had game-like characteristics.

China is now creating platforms that are multilingual, including translation services such as WeChat, that will be competing with services in Western countries. The growth of the social media market in China, as shown in Table 14.5, represents a scale that overshadows many countries. The role of virtual currency and currency platforms in the casual games market should not be underestimated. China has linked future service to cloud-based models.

Online gaming in the People's Republic of China represents one of the largest and fastest growing Internet business sectors globally, estimated at US $\$ 9.7$ billion with online gaming accounting for 90 per cent of this revenue:

The Chinese online gaming industry illustrates two striking facts. The first is that the number of consumers and their spending have grown extraordinarily fast: in absolute terms far more people are online to shop, play games, search, watch videos and use social media in China than in any other country. The second is that consumers are spending almost all of that time and money on Chinese Internet platforms. (De Prato Feijoo, and Simon 2014)

Cloud-enabled business models will play a major role in monetizing online games and casual games in particular. In a cloud-based system, the critical functions of marketing sales and customer relationship management (CRM) services can be obtained from a cloud computing company such as salesforce. com with much greater flexibility and reduced cost. Depending on company requirements, cost and speed, the complexity of the service can be adjusted according to need. Small- and medium-scale game developers can access the expensive CRM software by buying it as a service from some cloud-enabled companies instead of obtaining the whole software platform at a higher cost. 
Table 14.5 Main platforms for social media in China

\begin{tabular}{|llll|}
\hline Program & Owner & $\begin{array}{l}\text { Active users } \\
\text { (millions) }\end{array}$ & $\begin{array}{l}\text { Platforms } \\
\text { available } \\
\text { on }\end{array}$ \\
\hline OQ & $\begin{array}{l}\text { Tencent } \\
\text { Holdings }\end{array}$ & 800 & $\begin{array}{l}\text { Desktop, } \\
\text { Mobile }\end{array}$ \\
Ozone & $\begin{array}{l}\text { Tencent } \\
\text { Holdings }\end{array}$ & 600 & $\begin{array}{l}\text { Desktop, } \\
\text { Mobile }\end{array}$ \\
Weixin (WeChat) & $\begin{array}{l}\text { Tencent } \\
\text { Holdings }\end{array}$ & 355 & $\begin{array}{l}\text { Mobile only } \\
\text { Sina Weibo }\end{array}$ \\
$\begin{array}{l}\text { Sina } \\
\text { Corporation }\end{array}$ & 536 & $\begin{array}{l}\text { Mobile, } \\
\text { Desktop }\end{array}$ \\
\hline Tencent Weibo & $\begin{array}{l}\text { Tencent } \\
\text { Holdings }\end{array}$ & 250 & $\begin{array}{l}\text { Mobile, } \\
\text { Desktop }\end{array}$ \\
\hline RenRen & $\begin{array}{l}\text { China } \\
\text { InterActive } \\
\text { Corp }\end{array}$ & 100 & $\begin{array}{l}\text { Mobile, } \\
\text { Desktop }\end{array}$ \\
\hline Yang Bo & 100 & $\begin{array}{l}\text { Mobile, } \\
\text { Desktop }\end{array}$ \\
\hline
\end{tabular}

Source: Adapted from Chinese Internet Networking Information Centre (http://cnnic.cn/).

The software companies also benefit because they can access a larger client base at lower prices. Figure 14.3 compares these two revenue mechanisms.

The benefits of this new type of model include that: games can be bundled differently according to the player requirements, and players need not buy the whole game and worry about its maintenance or future upgrade. The responsibility now resides with cloud-based service provider.

\section{Conclusion}

Casual games and their freemium models are increasingly going to be the entrée to currency platforms in cloud-based services - real and virtual and elsewhere online. The rise of item brokers demonstrates the shift from games as retail to games as service. Virtual monies of one game can be exchanged for virtual monies of other games through online brokers such as 


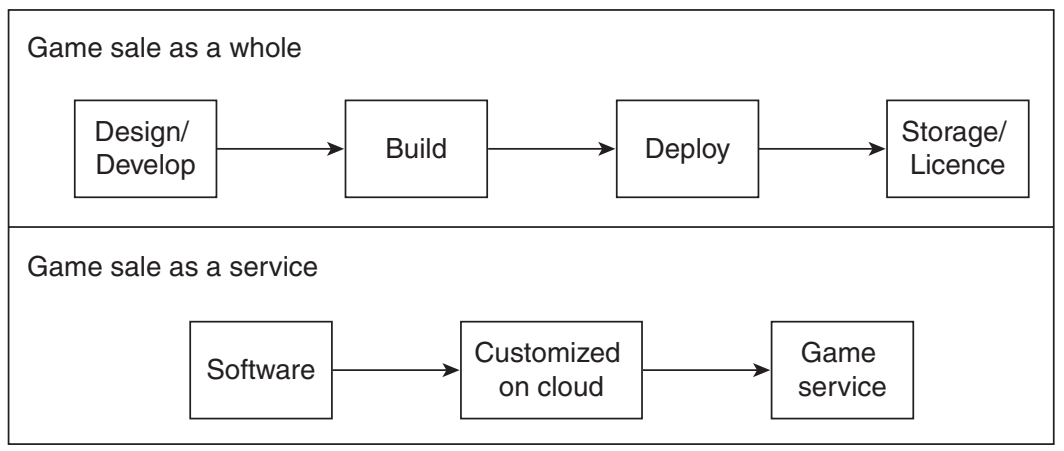

FIGURE 14.3 Flow of the new games revenue ecosystem.

Items Mania or Items Bay. Items brokers make profit by taking a cut, around 5 per cent, of the transaction. They in return provide security and safety of transactions. Ten years ago, in 2004, the Korean items trade market was already worth US $\$ 800$ million and that grew to US $\$ 1.5$ billion by 2008 (see Lehdonvirta 2008, 2009; Yoon 2009; KCCA 2012). This market size exceeds revenue earned by many game developers. Economies of this size of course experience all the characteristics of traditional economies, including inflation. Economies of this size have also not gone unnoticed in terms of potential tax revenue and regulation, beyond the compass of this chapter.

In this chapter the authors have argued that the overall games economy cannot now be separated from the casual games economy and the platformization of the value chain. Platforms have become the new intermediaries. The industry has witnessed a process of disintermediation where developers can reach consumers directly and from re-intermediation in the value chain. The nature of the platforms is not the only thing that has change. The gamers themselves are now diverse. The hardcore gamer is now joined by the mid-core gamer who wants a fuller experience, but still casual, and the casual games gamer who wants a quick fix.

In the long term there's no reason why the casual [games business] would not overcome the hardcore business because there are more people that are interested in buying casual. Yves Guillemot, Ubisoft CEO. (Evangelho 2013)

\section{References}

Bourdieu, P. and L. J. D. Wacquant. 2005. An Invitation to Reflexive Sociology. Cambridge: Polity Press.

Castronova, E. 2006. Synthetic Worlds: The Business And Culture Of Online Games. Chicago: The University of Chicago Press. 
Casual Games Association (CGA). 2013. Social Network Games 2012. Casual Games Sector Report.

De Prato, G., C. Feijóo, D. Nepelski, M. Bogdanowicz and J.P. Simon. 2010. 2010: Born Digital, Grown Digital: The European Videogames Industry. European Commission Institute for Prospective Technological Studies (IPTS). http://ipts. jrc.ec.europa.eu/publications/pub.cfm?id=3759.

De Prato, G., C. Feijoo and J.P. Simon. 2014. 'Innovations in the Video Game Industry: Changing Global Markets'. In P. Chantepie, L. Michaud, L. Simon and P. Zackariasson (eds), Video Game Business Models and Monetization. Communications \& Strategies 94. France: Digiworld, 17-38.

Dibbell, J. 2012. 'The Life Of The Chinese Gold Farmer'. The New York Times.

Evangelho, J. 2013. 'Massive Casual Gaming Footprint: Is The "Hardcore" Audience Disappearing?' Forbes, 1/2/2013. http://www.forbes.com/sites/ jasonevangelho/2013/01/02/2012s-massive-casual-gaming-footprint-is-thehardcore-audience-disappearing/.

Feijoo, C. 2012. An Exploration of the Mobile Gaming Ecosystem from Developers' Perspective in the Video Game Industry: Formation, Present State, and Future, P. Zackariasson (ed.), 76-95. New York and London: Routledge.

Korea Creative Content Agency (KCCA). 2012. Main Statistics of Korea's Content Market. http://www.kocca.kr/eng/industry/trend/index.html.

Han, Z. and F. Xu. 2014. 'Identifying The "Wolves" Through The Development Of The Red Bag By Tencent' (Cong weixin hongbao de yan fa gushi kan Tengxun de langxing), IT Times Weekly, 2014. http://mp.weixin.qq.com/s?__biz=MjMy NTI3NTU4MQ $==\& \mathrm{mid}=200035876 \& \mathrm{id} x=4 \& \mathrm{sn}=351215 \mathrm{~b} 26 \mathrm{f} 71 \mathrm{fe} 90 \mathrm{~d} 03 \mathrm{cf} 35$ 748f7d345\&scene=2\&uin=NzM5MDY4NTA0.

Heeks, R. 2010a. 'Gaming for Profits: Real Money from Virtual Worlds'. Scientific American. http://www.scientificamerican.com/article/real-money-from-virtualworlds/.

Heeks, R. 2010b. 'Understanding "Gold Farming" and Real-Money Trading as the Intersection of Real and Virtual Economies'. Journal of Virtual Worlds Research 2 (4): 3-27.

Juul J. 2012. A Casual Revolution: Reinventing Video Games And Their Players. MIT Press. http://groups.haas.berkeley.edu/marketing/sics/pdf_2013/xg.pdf.

Kocurek, C. A. 2012. 'Coin Drop Capitalism: Economic Lessons from the Video Game Arcade'. In Mark J. P. Wo (ed.), Before the Crash: Early Video Game History, 189-209. Detroit Michigan: Wayne State University Press.

Lehdonvirta, V. 2008. 'Real-Money Trade of Virtual Assets: New Strategies for Virtual World Operators'. In M. Ipe (ed.), Virtual Worlds, 113-37. Hyderabad: Icfai University Press.

Lehdonvirta, V. 2009. 'Virtual Item Sales as a Revenue Model: Identifying Attributes that Drive Purchase Decisions'. Electronic Commerce Research 9 (1): 97-113.

Lescop, D. and E. Lescop. 2014. 'Exploring Mobile Gaming Revenues: The Price Tag of Impatience, Stress and Release'. In P. Chantepie, L. Michaud, L. Simon and P. Zackariasson (eds), Video Game Business Models and Monetization. Communications \& Strategies 94. France: Digiworld, 103-22.

'Paying for Pixels. Virtual Goods Are Worth Real Money - And Cause Real Dilemmas'. The Economist, 10 December 2011. http://www.economist.com/ node/21541163. 
Phillips, R., W. Latham, D. Hodgson, J. Corden, J. Jordan, T. Minshall and L. Wharton. 2009. In Search Of Excellence: A Comparative Business Model Assessment Of Value-Creation Capabilities In The Computer Games Industry. Northwest Regional Development Agency.

Rayna, T. and L. Striukova. 2014. "“Few to Many": Change of Business Model Paradigm in the Video Game Industry'. In P. Chantepie, L. Michaud, L. Simon and P. Zackariasson (eds), Video Game Business Models and Monetization. Communications \& Strategies 94. France: Digiworld, 61-82.

Seto, T. P. 2009. 'When is a Game Only a Game?: The Taxation of Virtual Worlds'. University of Cincinnati Law Review 77: 1027-52.

Simon, P. 2011. The Economics Of The Video Games Industry. Innovation \& Regulation in Digital Services. Paris: Chair/ PTS workshop, 13 September 2011.

Wi, J. H. 2009. Innovation and Strategy of Online Games. London: Imperial College Press.

Wolf, M. J. P. 2008. The Video Game Explosion: A History from PONG to PlayStation and Beyond. Westport Connecticut: Greenwood Publishing Group, 4.

Woodcock, B. S. 2008. 'An Analysis of MMORG Subscription Growth'. Tech Rep ION Game Conference.

Yoon, U. 2009. 'Real Money Trading in MMORPG Items From a Legal and Policy Perspective'. Journal of Korean Judicature 1: 418-77. 